\title{
Optimal Choice of Dairy Forages in Eastern Australia
}

\author{
M. Neal, ${ }^{\star 1}$ J. Neal, $†$ and W. J. Fulkerson‡ \\ *Risk and Sustainable Management Group, University of Queensland, St. Lucia, Queensland 4072, Australia \\ †New South Wales Department of Primary Industries, Menangle, New South Wales 2570, Australia \\ \#Faculty of Veterinary Science, University of Sydney, Camden, New South Wales 2570, Australia
}

\begin{abstract}
Although several forage species such as perennial ryegrass are predominant, there is a wide range of forage species that could be grown in subtropical and temperate regions in Australia as dairy pastures. These species have differing seasonal patterns of growth, nutrient quality, and water-use efficiency, as demonstrated in a large experiment evaluating over 30 species at the University of Sydney (Camden, New South Wales, Australia). Some species can be grazed, whereas others require mechanical harvesting, which incurs a further cost. Previous comparisons of species that relied on yield of dry matter per unit of some input (typically land or water) did not simultaneously take into account the season in which forage is produced, or other factors related to the costs of production and delivery to the cows. To effectively compare the profitability of individual species, or combinations of species, requires the use of a whole-farm, multiperiod model. Linear programming was used to find the most profitable mix of forage species for an irrigated dairy farm in a warm temperate irrigation region of $\mathrm{New}$ South Wales, Australia. It was concluded that for a typical farmer facing the prevailing milk and purchased feed prices with average milk production per cow, the most profitable mix of species would include a large proportion of perennial ryegrass (Lolium perenne) and prairie grass (Bromus willdenowii). The result was robust to changes in seasonal milk pricing and a move from year-round to a more seasonal calving pattern.
\end{abstract}

Key words: forage, grazing, whole-farm, linear programming

\section{INTRODUCTION}

The dairy regions in Australia extend from subtropical to Mediterranean and temperate climates, and so there are many forage species that could be grown as forages

Received October 5, 2006.

Accepted February 20, 2007.

${ }^{1}$ Corresponding author: m.neal@uq.edu.au for dairy production. Currently, the dominant forage grazed by dairy cows on the majority of Australian dairy farms consists of perennial ryegrass (Lolium perenne) and annual ryegrasses (Lolium multiflorum), particularly in southern (temperate) Australia. This is because of the relative ease of management, its high quality, and ability to grow for most of the year. On many farms other forage species are sown with ryegrass (e.g., white clover, Trifolium repens), provide grazed feed when perennial ryegrass is not in production (e.g., kikuyu, Pennisetum clandistinum), or are harvested mechanically for silage (e.g., corn, Zea mays).

The appropriate species to select, and in what proportion they should be grown, is a complex problem. Historically, selection between species and, in particular, between varieties of a species has been biased toward the consideration of DM yield (McMeekan, 1956). It has been shown that for many farms, energy is the most common constraint to milk production (Fulkerson, 2000). Thus, the quality of feed is most appropriately measured by $\mathrm{ME}$ and this has become an important criterion for farmers and farm advisors when selecting forage species. Another factor, of increasing importance given the trend toward increasing water prices, is the water-use efficiency of forage species (Neal et al., 2005). There is a range of other aspects to take into account when choosing forage species, including nutrient content (e.g., protein and fiber), temporal aspects (i.e., when does the forage production occur), and harvesting aspects (i.e., can it be grazed or does it require mechanical harvesting).

The most effective choice of forage species to grow on a farm to meet the farmer's objectives can be addressed through a whole-farm system approach. In this paper, a linear programming model of a dairy farm was designed to maximize the profit for a farmer by choosing a mix of forage species and supplements to feed the dairy cattle. The data on forage yield and quality was obtained from a comprehensive study comparing over 30 forage species, grown under identical climatic and edaphic conditions, where soil nutrient and moisture were nonlimiting to growth. The cow nutritional requirements were based on the work underlying the CAMDAIRY computer model (Hulme et al., 1986). 
The aims of this paper were to determine 1) the profitmaximizing mix of forages for a farm that calves yearround at constant milk prices, located in a similar area to where the study was undertaken and irrigation water could be purchased; 2) the impact of using alternative criteria to profit for choosing forages; 3 ) the effect of progressively removing the most profitable forage species from the available options; and 4) the effect of seasonal calving and variation in milk prices throughout the season on the optimal forage mix.

The first 2 objectives were chosen to demonstrate the mix of forages that would maximize profits and to illustrate how alternative criteria that are sometimes considered (such as maximizing DM yield or water-use efficiency) could be detrimental to the farm's profit. The remaining aims were chosen to consider the sensitivity of profit if the farmer was not able or prepared to plant the species recommended by the model, as well as the case in which the farmer faced different prices or considered seasonal calving patterns.

\section{MODEL DESCRIPTION}

\section{Modeling Approach}

A linear programming (LP) format was chosen to ensure the best use of inputs (e.g., land, forages, and labor) for each modeled scenario. The LP approach takes into account that specifying that a certain area of a particular forage will be grown may require other inputs to be altered to maximize the profit (McCall and Clark, 1999).

Linear programming has previously been used in grazing-based dairy models, although they have tended to focus on issues other than forage choice, with simpler approaches to animal nutrition. For example, Olney and Kirk (1989) examined strategic issues important to Western Australian dairy farms such as stocking rate, beef activities, hay production, and grain usage. Batterham et al. (1993) examined the strategic issues facing New South Wales (NSW) dairy farmers, including milk quota choice, pasture combinations, and fodder conservation. Tozer and Huffaker (1999) also used LP to examine quota and calving pattern issues for NSW dairy farmers. Neal (1999) examined strategic options for NSW farmers given the expected removal of the quota system. McCall and Clark (1999) used LP to examine grazing-based dairy systems in the northeastern United States and in New Zealand. Strategic issues of stocking rates, calving patterns, and the proportion of area planted to crops and pastures were examined simultaneously with tactical options of nitrogen fertilizer use and feeding levels.

Linear programming requires the use of linear equations to model relationships. However, some important relationships were considered to be nonlinear. For example, the diminishing marginal returns of milk production in response to increased energy intake. These relationships can be approximated by a series of linear segments.

The objective function was to maximize the profit before tax and interest expense for a dairy farm over a single year. Revenue came from milk sales, cull sales (based on a 25\% replacement rate), and leasing land. Expenses were categorized by their cost driver. These cost categories included cow costs (e.g., artificial insemination, herd recording, veterinary, agistment of replacements), forage establishment costs (e.g., seed), fertilizer costs, irrigation water costs, cost of making conserved feed, cost of feeding conserved feed, purchased feed cost, and labor cost. The equation defining profit is given by

$$
\begin{aligned}
& Z=\sum_{s=1}^{12} \text { MilkSales }_{s}+\text { CullSales }_{s}+\text { LeaseOut }_{s} \\
& \text { - } \text { Cow Costs }_{s}-\text { ForageCosts }_{s}-\text { FertilizerCosts }_{s} \\
& \text { - IrrigationCosts } \text { I }_{s} \text { - MakingConservedCosts }{ }_{s} \\
& \text { - FeedingConservedCosts }{ }_{s}-\text { PurchasedFeedCosts }_{s} \\
& \text { - LaborCosts } \text { LFixedCosts }_{s} \text { ) } \\
& =\sum_{s=1}^{12}\left(\sum_{m=1}^{1}\left(30 . R_{m}^{\text {MilkPrice }} \cdot A_{m, s}^{\text {MilkProduced }}\right)\right.
\end{aligned}
$$

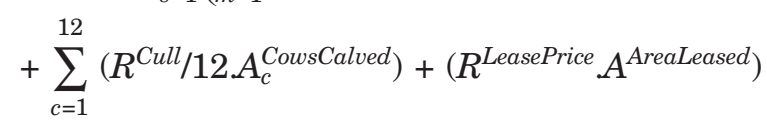

$$
\begin{aligned}
& -\sum_{c=1}^{12}\left(C_{c, s}^{\text {CowCost }} \cdot A_{c, s}^{\text {CowsCalved }}\right)-\sum_{f=1}^{20}\left(\left(\left(C_{s, f}^{\text {Establish }} / D_{f}^{\text {Rotation }}\right)\right.\right. \\
& +\left(L_{s, f}^{\text {Establish }} / D_{f}^{\text {Rotation }} \cdot C^{\text {Tractor }}\right)+\left(L^{\text {Top }} \cdot D_{s, f}^{\text {Top }} \cdot C^{\text {Tractor }}\right)
\end{aligned}
$$

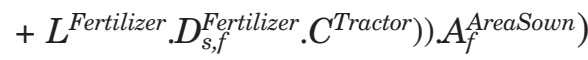

$$
\begin{aligned}
& -\sum_{e=1}^{2}\left(C_{e}^{\text {Fertilizer }} \cdot A_{e}^{\text {FertApplied }} / 12\right) \\
& -\sum_{f=1}^{20}\left(C^{\text {Water }} \cdot D_{s, f}^{\text {WaterReq }} \cdot A_{f}^{\text {AreaSown }}\right) \\
& -\sum_{h=1}^{2} \sum_{f=1}^{20}\left(\left(C_{h, s, f}^{M a k e C o n s e r v e}+L_{h, s, f}^{\text {MakeConserve }} \cdot C^{\text {Tractor }}\right) \cdot A_{s, f, h}^{\text {MakeConserve }}\right) \\
& -\sum_{h=1}^{2} \sum_{c=1}^{12} \sum_{f=1}^{20}\left(\left(C_{h}^{\text {FeedConserve }}+L_{h}^{\text {FeedConserve }} \cdot C^{\text {Tractor }}\right) \cdot A_{s, c, f, h}^{\text {ConserveFed }}\right) \\
& -\sum_{g=1}^{12}\left(C_{g}^{\text {PurchasedFeed }} \cdot A_{s, g}^{\text {PurchasedFeed }}\right) \\
& \left.-\left(C^{\text {Labor }} \cdot A_{s}^{\text {LaborReq }}\right)-C^{\text {Fix }}\right)
\end{aligned}
$$

where $\mathrm{Z}$ = annual profit before tax (dollars); $R_{m}^{\text {MilkPrice }}=$ revenue per liter of fat and protein adjusted milk in 
market $m$ (dollars); $A_{m, s}^{\text {MilkProduced }}=$ volume of milk in market $m$ in month $s(\mathrm{~L} / \mathrm{d}) ; R^{\text {Cull }}=$ cull revenue per cow calved for the year (dollars); $A_{c}^{\text {CowsCalved }}=$ the number of cows calved in month $c$ of the year; $R^{\text {LeasePrice }}=$ revenue per hectare leased out (dollars); $A^{\text {AreaLeased }}=$ area leased out (ha); $C_{c, s}^{\text {CowsCost }}=$ cost per cow calved in month $c$ during month $s$ (dollars); $C_{s, f}^{\text {Establish }}=$ cost of establishing and maintaining 1 ha of forage $f$ in month $s$ (dollars); $D_{f}^{\text {Rotation }}=$ years between establishment and subsequent replanting of forage $f ; L_{s, f}^{E s t a b l i s h}=$ labor required to establish 1 ha of forage $f$ (dollars); $C^{\text {Tractor }}=$ cost per hour for use of a tractor (dollars); $L^{T o p}=$ labor required to top 1 ha $(\mathrm{h}) ; D_{s, f}^{T o p}=$ number of times topping is required for forage $f$ in month $s ; L^{\text {Fertilizer }}=$ labor required to fertilize 1 ha $(\mathrm{h}) ; D_{s, f}^{\text {Fertilizer }}=$ number of times fertilizer is spread for forage $f$ in month $s ; A_{f}^{\text {AreaSown }}=$ area sown to forage $f\left(\right.$ ha); $C_{e}^{\text {Fertilizer }}=$ cost per tonne of fertilizer $e$ (dollars); $A_{e}^{\text {FertApplied }}=$ amount of fertilizer $e$ applied (dollars); $C^{\text {Water }}=$ cost of buying and pumping 1 ML (megaliter) of water (dollars); $D_{s, f}^{\text {WaterReq }}=$ water requirement of each forage $f$ in month $s(\mathrm{ML}) ; C_{h, s, f}^{\text {MakeConserve }}=$ cost to make 1 ha of forage $f$ into conserved feed $h$ during month $s$ (dollars); $L_{h, s, f}^{\text {MakeConserve }}=$ labor required to make 1 ha of forage $f$ into conserved feed $h$ during month $s$ (h); $A_{s, f, h}^{\text {MakeConserve }}=$ volume of forage $f$ made into conserved feed $h$ during month $s$ (t of DM); $C_{h}^{\text {FeedConserve }}=$ cost per tonne of DM to feed conserved feed $h$ (dollars); $L_{h}^{\text {FeedConserve }}=$ labor required to feed $1 \mathrm{t}$ of conserved feed $h(\mathrm{~h}) ; A_{s, c, f, h}^{\text {ConserveFed }}=$ volume of conserved feed $h$ made from forage $f$ fed each day in month $s$ to cows calved in month $c\left(\mathrm{~kg}\right.$ of DM); $C_{g}^{\text {PurchasedFeed }}=$ cost per tonne of asfed purchased feed (dollars); $A_{s, g}^{\text {PurchasedFeed }}=$ volume of purchased feed $g$ bought in period $s$ (t, as-fed); $C^{L a b o r}=$ cost of labor including on-costs per hour (dollars); $A_{s}^{\text {LaborReq }}=$ labor required in month $s(\mathrm{~h})$; and $C^{\text {Fix }}=$ fixed costs per month $s$.

\section{Area Allocation}

The area of the farm was assumed to be 200 ha. The farm could be sown with 20 individual forages for the year. There were also 16 combinations of winter and summer species that could be grown one after the other on the same area within a year. Hence, the farmer had 36 alternatives according to which parts of the farm could be sown. Area could also be leased out to alternative uses at the annual rate of $\mathrm{A} \$ 375 / \mathrm{ha}$. The equation summarizing the allocation of area was

$$
\sum_{f=1}^{36}\left(A_{f}^{\text {AreaSown }}\right)+A^{\text {AreaLeased }} \leq 200 .
$$

\section{Forage Production and Utilization}

Forage was produced in accordance with the data from the Camden forage experiment after the DM yields were adjusted to expected DM yields under commercial farm conditions. In general the yields were reduced by 15 to $35 \%$. The adjustment process is further described in the following section. Once forage was produced it could be grazed by cows or conserved as either hay or silage. Conservation was subject to a loss factor of $10 \%$ to account for losses when harvesting and feeding out under good management conditions (A. Kaiser, NSW DPI, Wagga, NSW, Australia; personal communication). The equation relating consumption and utilization was

$$
\begin{gathered}
30 . A_{s, c, f}^{\text {ForageGrazed }}+1,000 \cdot A_{s, f, h}^{\text {MakeConserved } /} \\
\left(1-D^{\text {ConservedLoss }}\right) \leq D_{f, s}^{\text {Production }} \cdot A_{f}^{\text {AreaSown }}
\end{gathered}
$$

where $A_{s, c, f}^{\text {ForageGrazed }}=$ volume of feed eaten each day by cows calved in month $c$ during month $s$ of forage $f(\mathrm{~kg}$ of DM); $D^{\text {ConservedLoss }}=$ the proportion of forage lost during the process of conservation and feeding out; and $D_{f, s}^{\text {Production }}=$ production of DM from 1 ha of forage $f$ during month $s$ (kg of DM).

\section{Conserved and Purchased Feed}

Conserved feed could be fed out in any period. The model assumed that forage conserved in month $t$ could be fed out in earlier months. This is similar to assuming that the inventory of feed at the end of the year will be higher or the same as at the start of the year. The equation relating the inventory of conserved feed to the conserved feed actually fed to cows was

$$
\begin{aligned}
& \sum_{c=1}^{12} \sum_{s=1}^{12}\left(30 . A_{s, c, f, h}^{\text {ConserveFed }}\right) \\
\leq & \sum_{s=1}^{12}\left(1,000 \cdot A_{s, f, h}^{\text {MakeConserved }}\right) .
\end{aligned}
$$

Purchased feed was fed during the month it was purchased, reflecting a low level of storage for purchased feeds. The equation allowing purchased feed to be supplied to any group of cows was

$$
\begin{gathered}
\sum_{c=1}^{12} \sum_{r=1}^{3}\left(30 . A_{s, c, g, r}^{\text {PurchFed }}\right) \\
\leq 1,000 \cdot D_{g}^{\text {PercentDM }} A_{s, g}^{\text {PurchasedFeed }}
\end{gathered}
$$


where $A_{s, c, g, r}^{\text {Purched }}=$ volume of feed eaten each day by cows calved in month $c$ during month $s$ of purchased feed $g$ at substitution level $r$ (kg of DM); $D_{g}^{\text {Percent } D M}=$ the percentage DM of feed $g$; and $A_{s, g}^{\text {PurchasedFeed }}=$ Amount of feed $g$ purchased in month $s$ (t, as-fed).

\section{Herd Dynamics}

The herd was assumed to consist of Holstein-Friesian cows with a mature weight of $550 \mathrm{~kg}$. Replacements were reared off the farm at an annual cost of $\mathrm{A} \$ 250$ per head (W. J. Fulkerson, unpublished data), before entering the herd at first calving at the age of 2 . The replacement rate was assumed to be $25 \%$. The average age of the milking herd was assumed to be $3.5 \mathrm{yr}$. Rather than model the nutritional requirements and milk production of each age class of the milking herd separately, it was considered accurate enough to model the herd based on a cow whose average age and production corresponded to that of the herd.

\section{Nutrition: DM}

It was assumed that cows had a maximum level of appetite, although the actual amount of feed that could be eaten was adjusted for quality and substitution effects in a similar way to that proposed by Hulme et al. (1986). The cow was assumed to have a total intake of $3.08 \%$ of BW when eating good quality roughage per day, where forages with OM digestibility of $74 \%$ are considered good quality roughage (Hulme et al., 1986). For an assumed weight of $550 \mathrm{~kg}$, each cow would then consume a maximum voluntary intake of $16.94 \mathrm{~kg}$ of $\mathrm{DM} / \mathrm{d}$. The maximum was lower for early lactation, being $80 \%$ of the maximum in the first month of lactation and $96 \%$ in the second month of lactation (Vladiveloo and Holmes, 1979). Intake was also reduced during the dry period (Holmes et al., 2002).

Intake was adjusted for digestibility of the forages. The CAMDAIRY program used the concept of relative digestibility to adjust the maximum voluntary intake upward for more-digestible feeds and downward for less-digestible feeds. Relative digestibility was calculated as the OM digestibility of a forage divided by that of good quality roughage (74\% OM digestibility). In the model presented here, the maximum voluntary intake was considered as the capacity to consume 16.94 fill units, where 1 fill unit corresponds to $1 \mathrm{~kg}(\mathrm{DM})$ of good quality forage ( $74 \%$ OM digestibility). For other forages, the amount of fill units used up by $1 \mathrm{~kg}$ (DM) of forage is determined as the inverse of CAMDAIRY's relative digestibility. Feeds with OM digestibility $<74 \%$ reduce consumption in a linear relationship. For example, 1 $\mathrm{kg}(\mathrm{DM})$ of $55 \% \mathrm{OM}$ digestibility feed would use 1.54

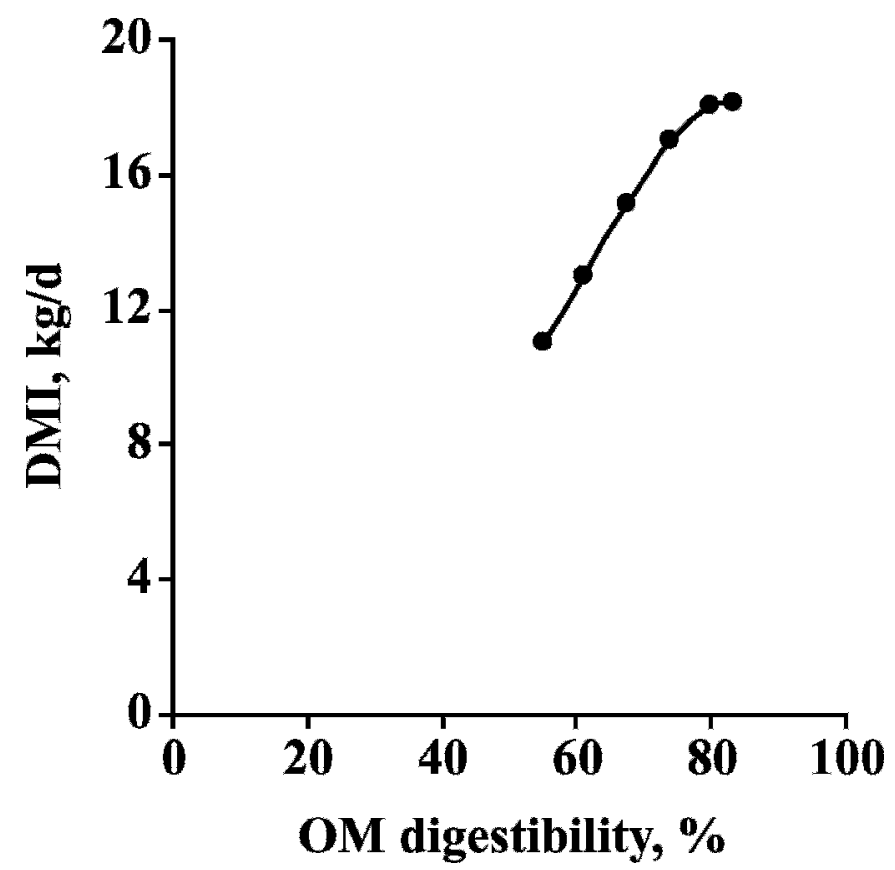

Figure 1. Potential DMI adjusted for digestibility.

fill units. Forages with OM digestibility above $74 \%$ increased consumption, but at a diminishing rate; this relationship is shown in Figure 1. Holmes et al. (2002) note that intake increases with digestibility up to $80 \%$ but cautions the use of digestibility as a predictor of intake, citing other factors such as chop length and species differences. Alternative predictors such as NDF content (Mertens, 1997) have been found useful for some forages, but not legumes. Although a more detailed intake model may have better predicted overall intake, it would also have become substantially more difficult to implement in the LP context.

When feeding concentrates such as good quality grain, forage intake is reduced but total intake increases. This is called the substitution effect, and the relationships of Moran and Trigg (1985) are used. These relationships specify that when good quality concentrates make up less than $25 \%$ of the diet, each marginal kilogram DM of concentrate reduces forage intake by 0.64 fill units. In other words, overall intake has increased by $0.36 \mathrm{~kg}$ if both the pasture and concentrate are of good quality. When concentrates are between 25 and $50 \%$ of the diet, each marginal kilogram reduces forage intake by 0.84 fill units. For concentrate intakes over $50 \%$ of the diet, each marginal kilogram reduces forage intake by 1.22 fill units. Similar to forage intake, the quality of concentrates is used to adjust the fill units and potential intake of the concentrate. 
The cow may consume purchased feeds, forage by grazing, or conserved feeds; this relationship, including quality adjustments and substitution is given by equation 6:

$$
\begin{gathered}
\sum_{g=1}^{12} \sum_{r=1}^{3}\left(D_{g, r}^{\text {PurchFillUnits }} \cdot A_{s, c, g, r}^{\text {PurchFed }}\right) \\
+\sum_{f=1}^{12}\left(D_{s, f}^{\text {ForageFillUnits }} \cdot A_{s, c, f}^{\text {ForageFed }}\right) \\
+\sum_{f=1}^{36} \sum_{h=1}^{2}\left(D_{h, f}^{\text {ConserveFillUnits }} \cdot A_{s, c, f, h}^{\text {ConserveFed }}\right) \\
\leq\left(D_{c, s}^{\text {VolDMIntake }} \cdot A_{c}^{\text {NumberCows }}\right)
\end{gathered}
$$

where $D_{g, r}^{\text {PurchFillUnits }}=$ the amount of appetite used by the consumption of $1 \mathrm{~kg}$ of DM of purchased feed $g$ at substitution level $r(\mathrm{~kg}$ of $\mathrm{DM}) ; D_{s, f}^{\text {ForageFillUnits }}=$ the amount of appetite used by the consumption of $1 \mathrm{~kg}$ of DM of forage $f$ during month $s$ ( $\mathrm{kg}$ of $\mathrm{DM}$ ); $D_{h, f}^{\text {ConserveFillUnits }}=$ the amount of appetite used by the consumption of $1 \mathrm{~kg}$ of DM of conserved feed $h$ made from forage $f\left(\mathrm{~kg}\right.$ of DM); and $D_{c, s}^{\text {VolDMIntake }}=$ the voluntary daily appetite of a cow calved in month $c$ during month $s$ for a feed with a fill unit value of 1 ( $\mathrm{kg}$ of $\mathrm{DM})$.

A further constraint is required to ensure that the cow does not consume more than the prescribed percentage of concentrate at each substitution level. This is given by equation 7 :

$$
\begin{gathered}
\sum_{g=1}^{12}\left(A_{s, c, g, r}^{\text {PurchFed }}\right) \\
\leq\left(D_{r}^{\text {Substitution }} \cdot D_{c, s}^{\text {DMIntake }} \cdot A_{c}^{\text {NumberCows }}\right)
\end{gathered}
$$

where $D_{r}^{\text {Substitution }}=$ the percentage of the diet at each substitution level $r$ (kg of DM).

\section{Nutrition: Energy}

Energy is supplied to the cows by the consumption of purchased feed, grazed forage, and conserved forage. The cows demand energy for lactation and maintenance as well as the additional requirements for growth, fetal growth, and changes in body condition. The Standing Committee on Agriculture standards (1990) were used to determine maintenance requirements for a $550-\mathrm{kg}$ cow grazing pasture of $82 \mathrm{MJ}$ of ME/d. Adjustments were made for the growth of heifers and an assumed pattern of body condition change related to stage of lactation. Cows were assumed to calve at a BCS of 5.5 (on the 8-point scale of Earle, 1976), reach a BCS of 4 in mid lactation and BCS 5 at dry off, with each BCS point equating to $42 \mathrm{~kg}$ of live weight (SCA, 1990).

The equation ensuring that energy supply meets or exceeds energy demand is given in equation 8:

$$
\begin{gathered}
\sum_{g=1}^{12} \sum_{r=1}^{3}\left(D_{g, r}^{\text {PurchME }} \cdot A_{s, c, g, r}^{\text {PurchFed }}\right)+\sum_{f=1}^{12}\left(D_{s, f}^{\text {ForageME }} \cdot A_{s, c, f}^{\text {ForageFed }}\right) \\
+\sum_{f=1}^{36} \sum_{h=1}^{2}\left(D_{h, f}^{\text {ConserveME }} \cdot A_{s, c, f, h}^{\text {ConserveFed }}\right) \geq\left(D_{c, s}^{\text {OtherME }} \cdot A_{c}^{\text {NumberCows }}\right) \\
+\sum_{q=1}^{6}\left(D_{c, s, q}^{\text {LactationME }} \cdot A_{c, s, q}^{\text {MilkProd }}\right)
\end{gathered}
$$

where $D_{g, r}^{\text {PurchME }}=$ ME supplied by the consumption of $1 \mathrm{~kg}$ of DM of purchased feed $g$ at substitution level $r$ (MJ of ME $/ \mathrm{kg}$ of DM); $D_{s, f}^{\text {ForageME }}=\mathrm{ME}$ supplied by the consumption of $1 \mathrm{~kg}$ of DM of forage $f$ during month $s$ $\left(\mathrm{MJ}\right.$ of $\mathrm{ME} / \mathrm{kg}$ of DM); $D_{h, f}^{\text {ConserveME }}=\mathrm{ME}$ supplied by the consumption of $1 \mathrm{~kg}$ of DM of conserved feed $h$ made from forage $f(\mathrm{MJ}$ of $\mathrm{ME} / \mathrm{kg}$ of $\mathrm{DM}) ; D_{c, s}^{\text {OtherME }}=$ daily $\mathrm{ME}$ requirement for maintenance, growth, fetal growth, and change in body condition of a cow calved in month $c$ during month $s$ (MJ of $\mathrm{ME} / \mathrm{cow}$ ); $D_{c, s, q}^{\text {LactationME }}=\mathrm{ME}$ requirement of a cow calved in month $c$ during month $s$ for the production of $1 \mathrm{~L}$ of milk at the $q$ th segment of the production function (MJ of ME), with the production function described in more detail in the next section; $A_{c, s, q}^{\text {MilkProd }}=$ amount of milk produced by cows calved in month $c$ during month $s$ at the $q$ th segment of the production function $(\mathrm{L})$.

In calculating energy required for production, it was considered important to represent the diminishing response in milk production with respect to energy intake. The linearization of the production function chosen by Hulme et al. (1986) was implemented, giving 6 segments to approximate the production function. Figure 2 shows the production function for 3 different months of lactation and compares it to the response assumed by the fixed relationship suggested by ARC (1980). The segmented production function allows the optimal level of per-cow production to vary, with production increasing when the marginal cost of energy is low and decreasing with a high marginal cost of energy.

A restriction is required to ensure that production in each segment of the production function is below the maximum. This constraint is achieved through equation 9:

$$
A_{c, s, q}^{\text {MilkProd }} \leq\left(D_{c, s, q}^{\text {ProdRestriction }} A_{c}^{\text {NumberCows }}\right)
$$

where $D_{c, s, q}^{\text {ProdRestriction }}=$ the maximum amount of milk produced by a cow calved in month $c$ during month $s$ at the $q$ th segment of the production function $(\mathrm{L})$. 




Figure 2. Linearized production function at 2, 6, and 10 mo of lactation, compared with the ARC (1980) assumption.

The maximum daily milk production of a cow at each point in lactation can be found by using the lactation curve of Wood (1980), adjusted for maximum production of $6,000 \mathrm{~L} / \mathrm{cow}$ per yr. The model assumed the maximum daily production in each month was found by averaging the maximum daily production levels for each month, given a cow whose average age corresponded to that of the herd (Figure 3).

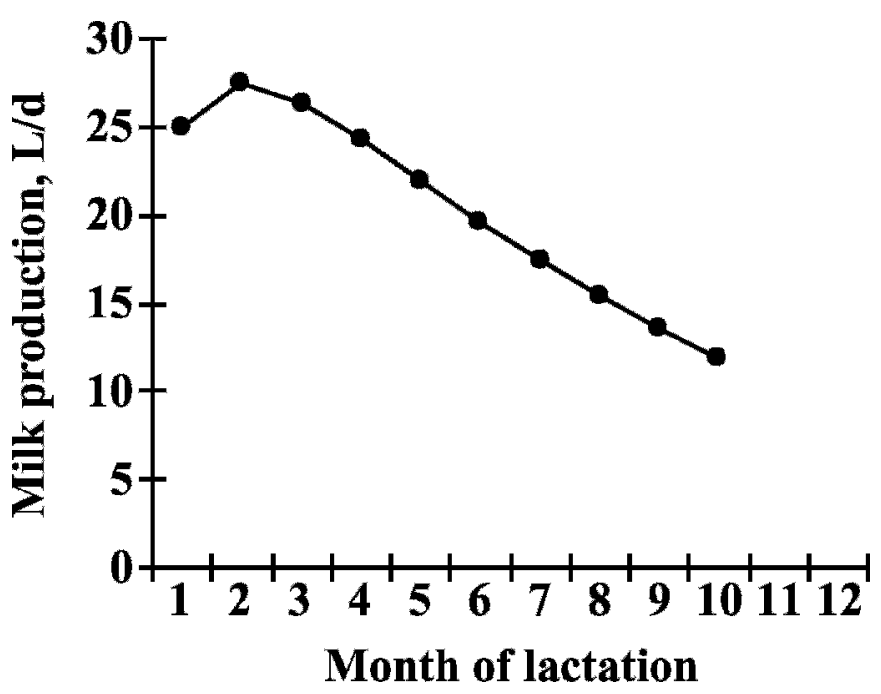

Figure 3. Maximum daily milk production (-) for a cow of average age and production for the herd in each month of lactation.

\section{Nutrition: Protein}

Protein supply was specified in terms of RDP and undegraded dietary protein (UDP). The requirement for RDP was calculated as $9 \mathrm{~g} / \mathrm{MJ}$ of $\mathrm{ME}$ from Holmes et al. (2002), which was in the range suggested by SCA (1990). The constraint calculating the ME intake is in equation 10 :

$$
\begin{aligned}
\sum_{g=1}^{12} & \sum_{r=1}^{3}\left(D_{g, r}^{\text {PurchME }} A_{s, c, g, r}^{\text {Purch }} \text { Ped }\right)+\sum_{f=1}^{12}\left(D_{s, f}^{\text {ForageME }} A_{s, c, f}^{\text {ForageFed }}\right) \\
& +\sum_{f=1}^{36} \sum_{h=1}^{2}\left(D_{h, f}^{\text {ConserveME }} \cdot A_{s, c, f, h}^{\text {ConserveFed }}\right)=A_{c, s}^{\text {MEIntake }}
\end{aligned}
$$

where $A_{c, s}^{M E I n t a k e}=$ daily $\mathrm{ME}$ intake of cows calved in month $c$ during month $s$ (MJ).

The constraint ensuring the RDP requirement is met is in equation 11 :

$$
\begin{gathered}
\sum_{g=1}^{12} \sum_{r=1}^{3}\left(D_{g}^{\text {PurchRDP }} \cdot A_{s, c, g, r}^{\text {PurchFed }}\right)+\sum_{f=1}^{12}\left(D_{s, f}^{\text {ForageRDP }} \cdot A_{s, c, f}^{\text {ForageFed }}\right) \\
+\sum_{f=1}^{36} \sum_{h=1}^{2}\left(D_{h, f}^{\text {ConserveRDP }} \cdot A_{s, c, f, h}^{\text {ConserveFed }}\right) \\
\geq 9 / 1,000 . A_{c, s}^{\text {MEIntake }}
\end{gathered}
$$

where $D_{g}^{\text {PurchRDP }}=$ RDP percentage of purchased feed $g$ $(\% \mathrm{RDP}) ; D_{s, f}^{\text {Forage RDP }}=\mathrm{RDP}$ percentage of forage $f$ during month $s$ (\%RDP); and $D_{h, f}^{\text {ConserveRDP }}=\mathrm{RDP}$ percentage of conserved feed $h$ made from forage $f$ (\%RDP).

The dietary needs of the animal could be met through the digestion of microbial protein or UDP from purchased feed, grazed forage, or conserved feed. It was assumed that microbial protein was $80 \%$ true protein, and the apparent digestibility of both types of protein was assumed to be 0.7 (SCA, 1990). These assumptions were used to calculate the supply of apparently digested protein leaving the stomach (ADPLS). The demands for ADPLS were from milk production (assumed to have $3 \%$ protein) and for nonmilk production needs such as endogenous fecal protein (15.2 $\mathrm{g} / \mathrm{kg}$ of DMI), endogenous urinary protein $(60 \mathrm{~g} / \mathrm{d})$, dermal loss $(13 \mathrm{~g} / \mathrm{d})$, gestation and BW change (SCA, 1990). The constraint determining the amount of RDP that could be transferred as microbial protein is in equation 12 :

$$
\begin{gathered}
\left.\left.\sum_{g=1}^{12} \sum_{r=1}^{3} D_{g}^{\text {PurchRDP }} \cdot A_{s, c, g, r}^{\text {Purch }}\right)+\sum_{f=1}^{12} D_{s, f}^{\text {ForageRDP }} \cdot A_{s, c, f}^{\text {ForageFed }}\right) \\
+\sum_{f=1}^{36} \sum_{h=1}^{3}\left(D_{h, f}^{\text {ConserveRDP }} \cdot A_{s, c, f, h}^{\text {ConserveFed }}\right) \geq A_{c, s}^{\text {RDPIntake }}
\end{gathered}
$$


The constraint calculating the actual DMI, a necessary step to determine endogenous fecal protein requirements, is in equation 13:

$$
\begin{aligned}
& \sum_{g=1}^{12} \sum_{r=1}^{3}\left(A_{s, c, g, r}^{\text {PurchFed }}\right)+\sum_{f=1}^{12}\left(A_{s, c, f}^{\text {ForageFed }}\right) \\
& +\sum_{f=1}^{36} \sum_{h=1}^{2}\left(A_{s, c, f, h}^{\text {ConserveFed }}\right)=\left(A_{c, s}^{\text {DMIntake }}\right)
\end{aligned}
$$

where $A_{c, s}^{\text {DMIntake }}=$ actual DMI of all cows calved in month $c$ during month $s$ ( $\mathrm{kg}$ of DM).

The constraint ensuring that ADPLS requirements were met is in equation 14 :

$$
\begin{gathered}
\left.\sum_{g=1}^{12} \sum_{r=1}^{3} D_{g}^{\text {PurchUDP }} \cdot A_{s, c, g, r}^{\text {Purched }}\right) / 0.7 \\
\left.+\sum_{f=1}^{12} D_{s, f}^{\text {ForageUDP }} \cdot A_{s, c, f}^{\text {ForageFed }}\right) / 0.7 \\
+\sum_{f=1}^{36} \sum_{h=1}^{2}\left(D_{h, f}^{\text {ConserveFed }} \cdot A_{s, c, f, h}^{\text {ConserveFed }}\right) / 0.7 \\
+A_{c, s}^{\text {RDPIntake }} /(0.8 * 0.7) \geq\left(15.2 / 1,000 * A_{c, s}^{\text {DMIntake }}\right) \\
+\left(D_{c, s}^{\text {ADPLSOther }} \cdot A_{c}^{\text {NumberCows }}\right)+\sum_{q=1}^{6}\left(0.03 * A_{c, s, q}^{\text {MilkProd }}\right)
\end{gathered}
$$

where $D_{g}^{\text {PurchUDP }}=$ UDP percentage of purchased feed $g(\% \mathrm{CP}) ; D_{s, f}^{\text {ForageUDP }}=$ UDP percentage of forage $f$ during month $s(\% \mathrm{CP}) ; D_{h, f}^{\text {ConserveUDP }}=\mathrm{UDP}$ percentage of conserved feed $h$ made from forage $f(\% \mathrm{CP})$; and $D_{c, s}^{A D P L O t h e r}=$ the minimum ADPLS requirement for endogenous urinary protein, dermal loss, gestation, and BW change per liter of milk of a cow calved in month $c$ during month $s$ (ADPLS).

The level of detail in describing protein requirements was considered sufficient since energy is generally the most limiting nutrient in diets except where significant quantities of maize silage are fed.

\section{Nutrition: Fiber}

The fiber in feeds was characterized by NDF, with the cows requiring a minimum level of NDF of $30 \%$ of intake, similar to the levels recommended by NRC (2001). Again, NDF could be supplied by purchased feed, grazed forage or conserved feed. The constraint ensuring the minimum NDF requirements were met is in equation 15 :

$$
\begin{gathered}
\left.\sum_{g=1}^{12} \sum_{r=1}^{3} D_{g}^{\text {PurchNDF }} \cdot A_{s, c, g, r}^{\text {Purch }}{ }^{12}\right)+\sum_{f=1}^{12}\left(D_{s, f}^{\text {ForageNDF }} \cdot A_{s, c, f}^{\text {ForageFed }}\right) \\
+\sum_{f=1}^{36} \sum_{h=1}^{3}\left(D_{h, f}^{\text {ConserveNDF }} \cdot A_{s, c, f, h}^{\text {ConserveFed }}\right) \\
\geq\left(D^{\text {NDFRequire }} \cdot A_{c, s}^{\text {DIntake }}\right)
\end{gathered}
$$

where $D_{g}^{\text {PurchNDF }}=\mathrm{NDF}$ percentage of purchased feed $g(\% \mathrm{NDF}) ; D_{s, f}^{\text {ForageNDF }}=\mathrm{NDF}$ of forage $f$ during month $s(\% \mathrm{NDF}) ; D_{h, f}^{\text {ConserveNDF }}=\mathrm{NDF}$ of conserved feed $h$ made from forage $f(\% \mathrm{NDF})$; and $D^{\text {NDFRequire }}=$ the minimum percentage NDF requirement of a cow calved in month $c$ during month $s$ (\%NDF).

\section{Fertilizer}

Each forage was estimated to have a certain nutrient requirement to grow the assumed yield. It was assumed that nutrient was applied through 2 types of fertilizer (urea and a blended fertilizer) as well as through manure from grazing and mechanical application of manure collected at the parlor. Manure production was related to the number of cows on the farm (J. Neal, unpublished data), and the fertilizer mix was purchased. The constraint ensuring that fertilizer requirements were met is in equation 16 :

$$
\begin{gathered}
\sum_{s=1}^{12} \sum_{f=1}^{12}\left(D_{s, f, e}^{\text {ForageFert }} \cdot A_{f}^{\text {AreaSown }}\right) \\
\left.\leq \sum_{s=1}^{12} \sum_{c=1}^{12}\left(D_{s, c, e}^{\text {ManureFert }} \cdot A_{c}^{\text {NumberCows }}\right)+1000 \cdot A_{e}^{\text {FertApplied }}\right)
\end{gathered}
$$

where $D_{s, f, e}^{\text {ForageFert }}=$ requirement of forage $f$ for fertilizer $e$ during month $s(\mathrm{~kg})$, and $D_{s, c, e}^{\text {ManureFert }}=$ the equivalent volume of fertilizer $e$ produced by a cow calving in month $c$ during month $s(\mathrm{~kg})$.

\section{Labor}

Many activities on the dairy farm require labor. These include forage establishment, topping to maintain pasture quality, fertilizer application, managing purchased feed, making conserved feed, feeding conserved feed, variable labor for milking cows, and fixed labor for maintenance and fencing. Labor could be supplied by owner labor or through the hire of labor. It was assumed that all labor was paid at the rate specified in the Australian Federal Pastoral Award, which was the same methodology used by ABARE (2006) in determining the return on assets (C. Mues, ABARE, Canberra, NSW; personal communication). The constraint 
ensuring that labor requirements were met is in equation 17:

$$
\begin{gathered}
\sum_{f=1}^{20}\left(\left(\left(L_{s, f}^{\text {Establish }} / D_{f}^{\text {Rotation }}\right)+\left(L^{\text {Top }} \cdot D_{s, f}^{\text {Top }}\right)\right.\right. \\
\left.\left.+\left(L^{\text {Fertilizer }} \cdot D_{s, f}^{\text {Fertilizer }}\right)\right) \cdot A_{f}^{\text {AreaSown }}\right) \\
+\sum_{g=1}^{12}\left(L^{\text {PurchasedFeed }} \cdot A_{s, g}^{\text {PurchasedFeed }}\right) \\
+\sum_{h=1}^{2} \sum_{f=1}^{20}\left(L_{h, s, f}^{\text {MakeConserve }} \cdot A_{s, f, h}^{\text {MakeConserve }}\right) \\
+\sum_{h=1}^{2} \sum_{c=1}^{12} \sum_{f=1}^{20}\left(L_{h}^{\text {FeedConserve }} \cdot A_{s, c, f, h}^{\text {ConserveFed }}\right) \\
+\sum_{c=1}^{12}\left(L_{c, s}^{\text {CowCost }} \cdot A_{c}^{\text {NumberCows }}\right)+L^{\text {Fix }} \leq A_{s}^{\text {LaborReq }}
\end{gathered}
$$

where $L^{\text {PurchasedFeed }}=$ labor required to handle each tonne of purchased feed (h); $L_{c, s}^{\text {CowsCost }}=$ labor required for each cow calved in month $c$ during month $s(\mathrm{~h}) ; L^{\text {Fix }}=$ amount of labor spent each month in fixed requirements (h); $A_{s}^{\text {LaborReq }}=$ labor required to be hired each month $s$ (h); and $L^{\text {OwnerLab }}=$ amount of unpaid labor supplied by an owner each month (h).

\section{Milk Sales}

Once milk was produced, it was assumed to be sold into the market at a price that could differ by months of the year. It was assumed that only one market existed, although it would be relatively simple to allow for multiple markets and contracts that are now offered by some processors.

\section{Calving Patterns and Stocking Rates}

Year-round production was assumed to occur, with equal numbers of cows calving in each month. This constraint is reflected in equation 18 :

$$
A_{c}^{\text {NumberCows }}=\sum_{c=1}^{12}\left(A_{c}^{\text {NumberCows }}\right) / 12 .
$$

It was assumed that there was a maximum stocking rate of 4 cows/ha, so for the 200-ha farm, no more than 800 cows could be calved during the year. This constraint is shown by equation 19 :

$$
\sum_{c=1}^{12}\left(A_{c}^{\text {NumberCows }}\right) \leq 800 .
$$

Table 1. Asset values (Australian dollars, $\mathrm{A} \$$ ) and rate of appreciation for different asset classes

\begin{tabular}{lccc}
\hline & \multicolumn{3}{c}{$\begin{array}{c}\text { Annual } \\
\text { rate of } \\
\text { appreciation, } \\
\%\end{array}$} \\
Asset class & $\begin{array}{c}\text { Value, } \\
\text { A } \$\end{array}$ & $\begin{array}{c}\text { Appreciation, } \\
\text { A } \$\end{array}$ \\
\hline Milking cows & 560,000 & 3 & 16,800 \\
Replacements & 160,000 & 3 & 4,800 \\
Irrigation equipment & 500,000 & -10 & $-50,000$ \\
Tractors & 200,000 & -20 & $-40,000$ \\
Plant and equipment & 200,000 & -20 & $-40,000$ \\
Rotary dairy & 800,000 & -6 & $-48,000$ \\
Sheds & 100,000 & -6 & $-6,000$ \\
Land & $2,000,000$ & 5 & 100,000 \\
Total & $4,520,000$ & & $-62,400$ \\
\hline
\end{tabular}

\section{Farm Assets}

Values for the farm assets were required to determine the return on assets. Assuming a level of appreciation (or depreciation) for different classes allowed the change in capital values (the capital return) to be calculated and added to the operating return to calculate an inclusive measure of return on assets. The total value of the farm was $\mathrm{A} \$ 4.6$ million with net depreciation of A $\$ 62,400$, with asset classes detailed in Table 1 . Asset values and rates of appreciation were considered with reference to current market values (M. Neal, unpublished data). For example, cows in the herd were valued at $\mathrm{A} \$ 700 / \mathrm{head}$, replacements averaged $\mathrm{A} \$ 400 / \mathrm{head}$, and bare land (in an irrigation area) at $\mathrm{A} \$ 10,000 / \mathrm{ha}$.

\section{DATA AND ASSUMPTIONS}

Data regarding plant yield and quality characteristics were the mean values for $2 \mathrm{yr}$ of an experiment carried out at Camden $\left(150^{\circ} 39^{\prime} \mathrm{E}, 34^{\circ} 3^{\prime} \mathrm{S}\right)$, NSW, Australia (Neal et al., 2005). The experiment was conducted on a clay alluvial soil (brown dermosol). The climate was warm temperate, dominated by large summer rainfalls. The mean maximum temperatures in the hottest month of January was $29.2^{\circ} \mathrm{C}$ and mean minimum temperature in the coldest month was $2.9^{\circ} \mathrm{C}$. Figure 4 shows the daily minimum and maximum temperatures, as well as monthly rainfall, averaged over the $2 \mathrm{yr}$ of the study.

The design of the experiment was a randomized complete block design. Each plot was $5 \mathrm{~m} \times 5 \mathrm{~m}$ with the center area of $2 \mathrm{~m} \times 2 \mathrm{~m}$ being optimally covered for irrigation by set sprinklers located in each corner of the smaller square. Irrigation was scheduled when soil moisture status reached a deficit of $30 \mathrm{~mm}$. To ensure that soil nutrients were not limiting forage growth, fertilizer was applied at a rate to replace nutrients removed after each harvest using a high-analysis NPKS 


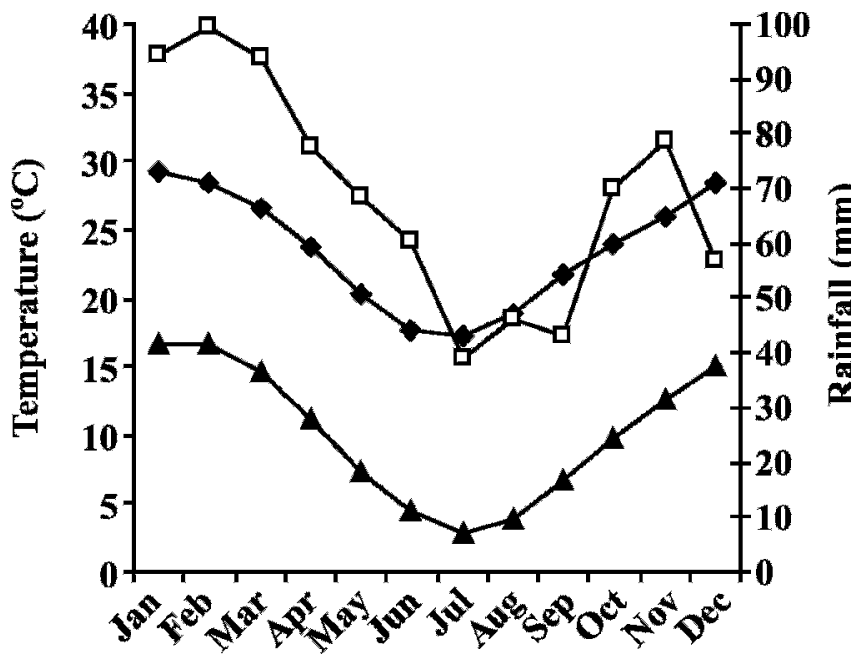

Figure 4. Mean daily minimum temperature (A), maximum temperature ( ), and mean monthly rainfall $(\square)$ at Camden, NSW, Australia.

fertilizer, except for the legumes where no $\mathrm{N}$ fertilizer was applied.

Each forage was harvested at the recommended stage of growth to optimize forage quality and regrowth after harvest. The optimal time and height of defoliation were known for some species, particularly for ryegrass (Lolium perenne), kikuyu (Pennisetum clandestinum), lucerne (Medicago sativa), and fescue (Festuca arundinacea) where substantial research has been undertaken. The harvest stage for other species was guided by principles based on allowing sufficient time for the plant to replenish its reserves (soluble carbohydrates) before the next defoliation, but before the oldest foliage began to senesce, leading to a fall in herbage quality and palatability. The application of these principles to development of optimal grazing management strategies as they apply to ryegrass is outlined in Fulkerson and Donaghy (2001).

Sowing rates used for each species are those recommended to apply to irrigated situations to maximize DM production. A representative herbage sample, taken from the harvested herbage over each of 4 seasons, dried at $70^{\circ} \mathrm{C}$ for $48 \mathrm{~h}$ in a forced-draught oven was analyzed for nutrients and rumen degradability characteristics (Fulkerson et al., 2007). The experiment considered 30 species in all, although only 20 relatively successful species were considered in the model (Table 2).

There were also combinations of some species that could be grown one after the other on the same area within a year. The species corn, sorghum, kikuyu, and lab lab were each paired with the following species: wheat, annual ryegrass, Persian clover, and rape to give 16 combinations that were also included in the model. The combinations chosen have been shown to be successfully grown in practice if appropriate management is imposed. The most complex would be the oversowing of various species into kikuyu in the autumn to provide winter feed when the kikuyu is semidormant or dormant. Oversowing kikuyu with annual ryegrass, annual clover, and to a lesser extent rape, is a common practice in Australia (W. J. Fulkerson, unpublished data). The oversowing of wheat into a kikuyu-based pasture is becoming more common in the wheat-growing regions to stabilize and protect soil over

Table 2. Abbreviation, common name, scientific name, and description of forage species considered in the model

\begin{tabular}{llll}
\hline Abbreviation & Common name & \multicolumn{1}{c}{ Scientific name } & \multicolumn{1}{c}{ Description } \\
\hline RS & Fodder radish & Rapanus sativus & Annual herb \\
RR & Rape & Brassica rapa & Annual herb \\
PE & Persian clover & Trifolium resupinatum & Annual pasture legume \\
LA & Lab lab & Lablab purpureus & Legume crop \\
CH & Chicory & Cichorium intybus & Perennial herb \\
PL & Plantain & Plantago lanceolata & Perennial herb \\
LU & Lucerne & Medicago sativa & Perennial pasture legume \\
RE & Red clover & Trifolium pratense & Perennial pasture legume \\
WC & White clover & Trifolium repens & Perennial pasture legume \\
CO & Corn & Zea mays & Summer crop (C4) \\
SO & Sorghum & Sorghum bicolor & Summer crop (C4) \\
RB & Biannual ryegrass & Lolium multiflorum & Temperate annual grass \\
WH & Wheat & Triticum aestivum & Temperate annual grass \\
RA & Annual ryegrass & Lolium multiflorum & Temperate annual grass \\
FE & Fescue & Festuca arundinacea & Temperate perennial grass \\
PH & Phalaris & Phalaris tuberosa & Temperate perennial grass \\
PR & Prairie grass & Bromus wildenowii & Temperate perennial grass \\
RP & Perennial ryegrass & Lolium perenne & Temperate perennial grass \\
PA & Paspalum & Paspalum dilatatum & Tropical grass (C4) \\
KI & Kikuyu & Pennisetum clandestinum & Tropical grass (C4) \\
\hline
\end{tabular}




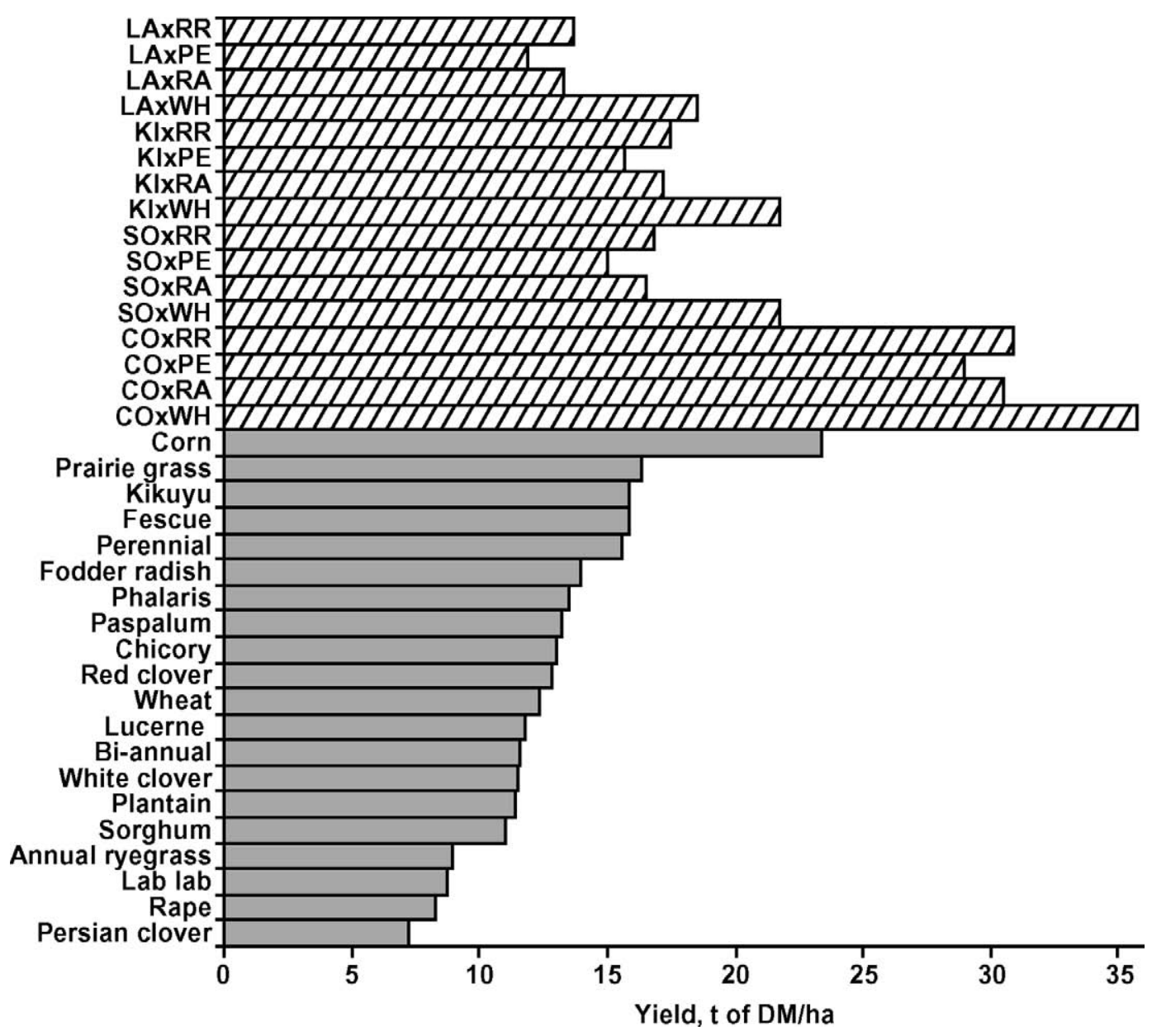

Figure 5. Adjusted yield of forages (solid bars) and combinations of forages (diagonal stripes). Forage combinations: LA = lab lab, KI = kikuyu, $\mathrm{SO}=$ sorghum, $\mathrm{CO}=$ corn, $\mathrm{RR}=$ rape, $\mathrm{PE}=$ Persian clover, $\mathrm{RA}=$ annual ryegrass, and $\mathrm{WH}=$ wheat.

the summer, provide grazing for sheep, and lower the water table.

The seasonal distribution of the growth of these species differs markedly. For example, wheat produces one large harvest in September, following some grazings from April through to July. Kikuyu's production is concentrated heavily in the summer months, whereas annual ryegrass produces mainly in the winter months. Perennial ryegrass is far more consistent, allowing DM to be grazed throughout the year, albeit with differing quality.

The forage species yields used in this model were reduced by $33 \%$ for grazed forages and $15 \%$ for corn in line with yields expected under best-practice commercial dairy farm conditions. Where combinations of species were considered in the model, the growing season, and hence the yields, for one or both forages were shortened accordingly. Figure 5 shows the adjusted yields for all forages and forage combinations considered in the model.
These yields and the subsequent ranking of forages were determined from a NSW experiment where water was not limiting growth. For areas to the north (e.g., Queensland) the relative performance of tropical species would improve, whereas in areas to the south (e.g., Victoria), the reverse would be true. For poorly managed irrigation and dryland situations the absolute yields would be lower, and relative rankings would also differ. Dryland situations would tend to favor those species with adaptations such as deeper roots (e.g., lucerne) over shallow rooted species like white clover (Neal et al., 2005).

\section{Productive Life of Forage Species}

The productive life of a forage sward is a determinant in its costs of production. The length of time between renovations is clear for annual species but for perennial species life span was based on local experience as well as observation of the decline in plant population in the 
Camden experiment. Thus, for the two C4 grasses, a life span of $10 \mathrm{yr}$ can be guaranteed. This also applies to prairie grass where appropriate management can be applied to allow seedling recruitment each year from naturally set seed. Phalaris, when managed correctly, should last at least $5 \mathrm{yr}$. White clover may last longer than $5 \mathrm{yr}$ but is often infected with nematodes or other pathogens and needs reseeding. It was known that perennial ryegrass should be resown after $2 \mathrm{yr}$ in this environment whereas fescue, chicory, and plantain would last $3 \mathrm{yr}$ based on experience from the experiment. Lucerne should last $3 \mathrm{yr}$, even under grazing.

\section{Year-Round Calving System at Flat Milk Prices}

The basic model assumed that year-round calving was used, with a uniform number of cows calving in each month through the year. The milk price of $\mathrm{A} \$ 0.33 /$ $\mathrm{L}$ was assumed to be uniform through the year, and similar to the price in 2006 (P. Neal, Neals' Dairy, Taree, NSW; personal communication).

Resources were priced at their current market value. Labor could be hired at a rate of $\mathrm{A} \$ 24 / \mathrm{h}$ throughout the year, which included tax, superannuation, and workers' compensation requirements. Fertilizer costs A $\$ 505 / \mathrm{t}$ for urea $(46 \% \mathrm{~N})$ and $\mathrm{A} \$ 360 / \mathrm{t}$ for a blend (P 4.4:K 25.0:S 5.5). Water costs $A \$ 45 / \mathrm{ML}$ for the right to use it and $\mathrm{A} \$ 22 / \mathrm{ML}$ for the electricity to pump it. Tractor running costs (fuel and oil plus repairs and maintenance) were $\mathrm{A} \$ 12 / \mathrm{h}$ of operation (NSW DPI, 2006). The contract costs of harvesting wheat or corn and storage in a pit for silage was $\mathrm{A} \$ 50 / \mathrm{t}$ of $\mathrm{DM}$.

\section{RESULTS AND DISCUSSION}

\section{Optimal Forage Mix}

The LP model was solved using the GAMS software (Brooke et al., 2005). The optimal forage mix, found by maximizing the profit for the farmer comprised 110 ha $(55 \%)$ of perennial ryegrass, 53 ha $(26.5 \%)$ of prairie grass, 19 ha of white clover, 12 ha of kikuyu oversown with annual ryegrass, 5 ha of plantain, and 1 ha of the kikuyu/wheat combination. The shadow price for land was A $\$ 1,090 /$ ha, implying that it could be profitable to lease in extra land if an annual lease was less than this value.

The farm calved the maximum number of cows (800), and produced 3.8 million $\mathrm{L}$ of milk for the year. On average, each cow produced $4,750 \mathrm{~L}$, or about $80 \%$ of their potential production. The farm operations involved only a small amount of forage conservation, with only $38 \mathrm{t}$ of conserved feed being fed out again. A large amount of purchased feed was used (1,230 t of DM), comprising corn grain (55\%) and barley grain (45\%).

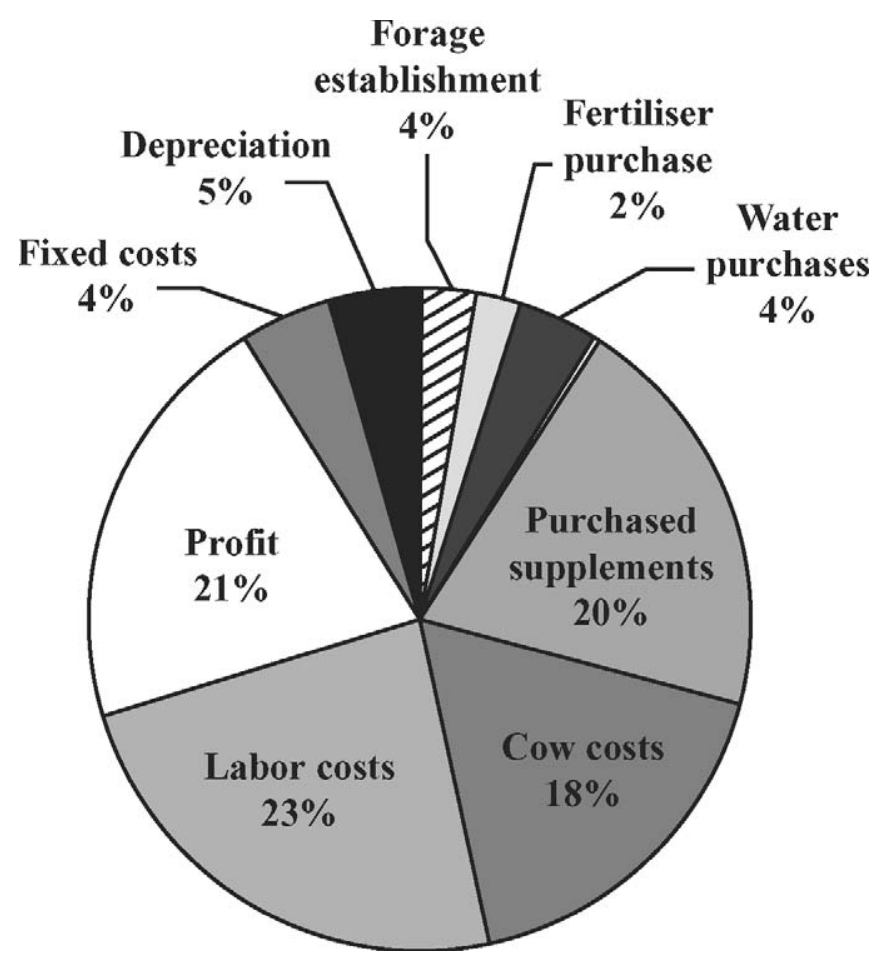

Figure 6. Costs and profit as a share of revenue.

Total revenue was $\mathrm{A} \$ 1.384$ million, with milk sales accounting for $91 \%$ of revenue. Labor costs (almost 6.5 full-time equivalents) accounted for $23 \%$ of revenue, with cow costs, bought supplement, and fixed costs being the next major cost categories. The resulting profit before interest and tax (but including changes in capital value) was $\mathrm{A} \$ 290,570$, or equivalent to $6.4 \%$ return on assets and management (Figure 6).

In view of the potentially important role of prairie grass as a forage for dairy cows, based on profit as a criterion, it is worthwhile discussing the management needs of this species. A long-term paddock experiment by Fulkerson et al. (2000) compared the production of prairie grass with perennial ryegrass and fescue. In the warm temperate/subtropical environment, perennial ryegrass and fescue had either disappeared or had been reduced dramatically after $3 \mathrm{yr}$, whereas prairie grass yields were near or above those of the establishment year.

\section{Comparison with Current Practice}

The biophysical output from the model can be compared with NSW dairy farms using 2004-2005 survey data collected by ABARE (2006). For example, the model farm, at 200 ha, was similar to the average NSW farm of 203 ha, although the model assumed all the area was irrigated, whereas NSW farms irrigated only 
Table 3. Forage area and return on assets associated with different criteria for forage choice

\begin{tabular}{lcr}
\hline Criterion for forage choice & Area (ha) of each species & $\begin{array}{c}\text { Return on } \\
\text { assets, } \%\end{array}$ \\
\hline Maximum profit & 110 perennial ryegrass, & 6.4 \\
& 53 prairie grass, & \\
& 19 white clover, \\
& 12 kikuyu/annual ryegrass, & \\
Maximum yield & 5 plantain, 1 kikuyu/wheat & -4.5 \\
Maximum yield, all grazed & 200 corn/wheat & 1.3 \\
Maximum energy density & 200 kikuyu/rape & 4.7 \\
Maximum water-use efficiency & 200 perennial ryegrass & -10.8 \\
\hline
\end{tabular}

29 ha on average. The optimal stocking rate in the model was 800 cows, being much higher than the average of 283 dairy cattle. This difference is mainly due to the stocking rate rising to match the higher pasture production resulting from the fully irrigated farm assumed by the model. Milk production per cow was lower in the model $(4,750 \mathrm{~L})$ than the average for NSW $(5,362 \mathrm{~L})$.

The model suggested the sowing of 2 ha to the wheat crop, with another 7 ha of plantain cut for silage production. This compared with 33 ha sown as crops or conserved as hay or silage on average for NSW farms (ABARE, 2006). The optimal allocation by the model suggested that most of the area would be planted to the temperate perennial prairie grass and perennial ryegrass. The predominant species used by NSW farmers currently are annual ryegrass and kikuyu (a tropical grass), although many other species are also used, including crops such as corn, and legumes such as lucerne (Fulkerson et al., 1993).

The level of assets for the model was A $\$ 4.52$ million compared with an average of $\mathrm{A} \$ 2.99$ million for the average NSW dairy farm (ABARE, 2006). The higher asset value for the model was due to a higher value of land (which was all irrigated), a higher value for tractors, plant, machinery, and irrigation equipment, and a higher number of dairy cattle. The return on assets from the model was $6.4 \%$ compared with the average for NSW dairy farmers of $8 \%$. However, if the capital appreciation of land and fixed assets was excluded, the model generated a 5.4\% return on assets compared with an average of $0.8 \%$ for NSW dairy farmers (ABARE, 2006). This suggests that there may be significant gains to implementing the optimal system, although it is difficult to determine how much of the gains result from the improved selection of forages and how much from the higher forage yields relative to the average on NSW farms.

\section{Alternative Criteria for Choosing Forages}

There are other criteria apart from profit maximization that could be used to choose forages. As an example, farmers may have been advised to use forages that maximize DM yield. The logical conclusion from this objective is to plant the entire area to the corn/wheat combination, with the result that the return on assets falls to $-4.5 \%$ (Table 3). Using this objective, the farm purchased less supplements (saving A $\$ 150,000$ ), but this saving was lost due to the larger cost of harvesting and then feeding out the corn and wheat. Higher establishment costs, fertilizer, and labor requirements, together with a 9\% reduction in milk production, were also partly responsible for the poor financial outcome.

A better criterion might have been to choose the forage that maximized DM yield from amongst the grazed forages, which was the kikuyu/rape combination. The return on assets for this criterion was $1.3 \%$, less than one-fourth of the profit-maximizing choice. This criterion saved the farm $\mathrm{A} \$ 110,000$ in water and supplementary feed costs relative to the base case, but an increase in establishment costs and an extra 1.5 full-time equivalents of labor canceled out the savings. Then there were additional costs in conservation and feeding, as well as a $14 \%$ reduction in milk production, that caused the return on assets to fall significantly from the base case.

The maximum energy density criterion would have led to perennial ryegrass being chosen. This resulted in a return on assets of $4.7 \%$, about three-fourths of the optimum. An increase in required purchases of supplements was responsible for most of the decrease in the return on assets. There were also small increases in the costs of establishment, fertilizer purchases, and labor requirements, together with a small reduction in milk production.

Choosing the forage with the highest water-use efficiency would have resulted in corn being grown; the return on assets was quite poor at $-10.8 \%$. The majority of the decline in profitability was due to the need to purchase very large amounts of supplement $(2,850 \mathrm{t}$ of $\mathrm{DM})$ to meet the nutritional needs of the herd. The high costs of harvesting and feeding out the corn and a $10 \%$ reduction in milk production were the other main factors. 


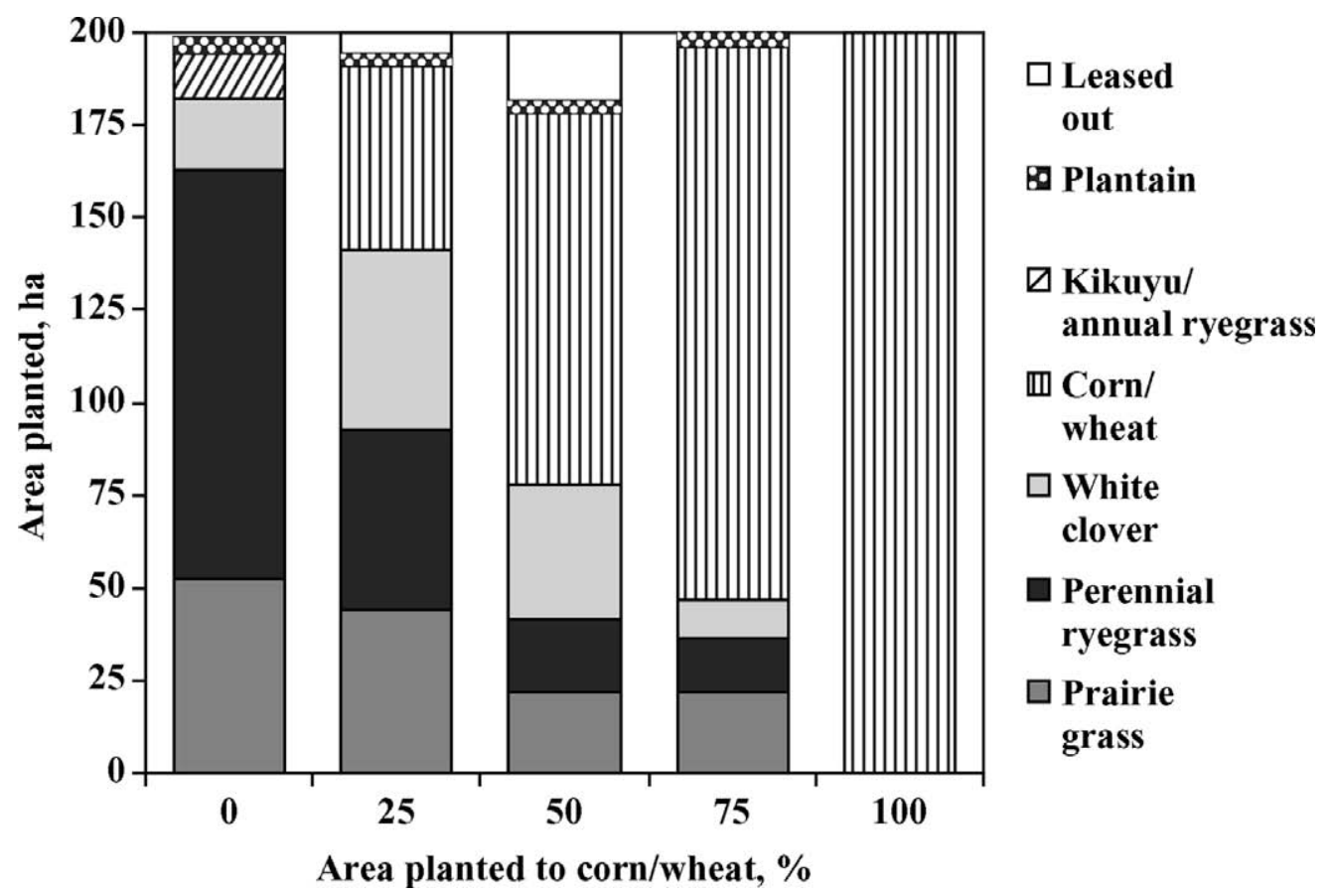

Figure 7. Use of land with an increasing area planted to the corn/wheat combination.

In summary, alterative criteria will not maximize profit and may significantly reduce profit. Although the maximum energy density criterion led to a result nearest the optimal profitability, this criterion may not be closest to maximum profitability in other situations.

Assuming that the farmer does plant some percentage of the area to the corn/wheat combination, the best use for the remainder of the land can be found assuming that profit maximization holds for other decisions. For example, if $25 \%$ of the land is used for the corn/wheat combination, increasing the area of white clover and leasing out a small amount of land ( $5 \mathrm{ha}$ ) is the best response. Increasing the corn/wheat area to $50 \%$ of the farm results in more land being leased out to another use (19 ha), with the remaining area sown mainly to white clover, prairie grass, and perennial ryegrass. Leasing out occurs, not because of a reduction in cow numbers, but because it is more profitable to use purchased feeds to complement the nutrients in the corn/ wheat combination than to grow them. This pattern is continued when the corn/wheat area is forced to $75 \%$ of the farm (Figure 7).

Introducing only a $25 \%$ area of corn/wheat leads to a relatively small reduction in the return on assets (from 6.4 to $4.9 \%$ ). This reduction is small because of the ease of substitution of other forages and purchased feed near the optimum. For example, the harvested corn and wheat halves the requirement for purchased supplement, and the increased use of white clover pro- vides forage that can be grazed from August to March when the wheat cannot be grazed. However, subsequent increases in the area of corn/wheat cause much larger decreases in the return on assets because of the diminishing marginal returns of substitutes. For example, purchased supplements cannot be further reduced without significant effects on the nutrition of the animals. The impact on profit from increasing the area planted to the corn/wheat combination is shown in Figure 8.

\section{Removing the Most Profitable Forages}

The optimal forage combination resulted in more than half the area being planted to perennial ryegrass, one of the most commonly used species. The best response of farmers who were not able or willing to use perennial ryegrass was tested by removing perennial ryegrass from the available options. The result was only a small reduction in the return on assets from 6.4 to $6.1 \%$, with large increases in the area of prairie grass, white clover, and the kikuyu/annual ryegrass mix (Table 4). Phalaris also entered the solution, probably due to its high yield in January when prairie grass is setting seed. A small reduction in milk production of $1 \%$ occurred. Small adjustments were made to the use of supplement purchases, with a 100-t DM increase in barley grain and a 50-t DM decrease in corn grain. Only 


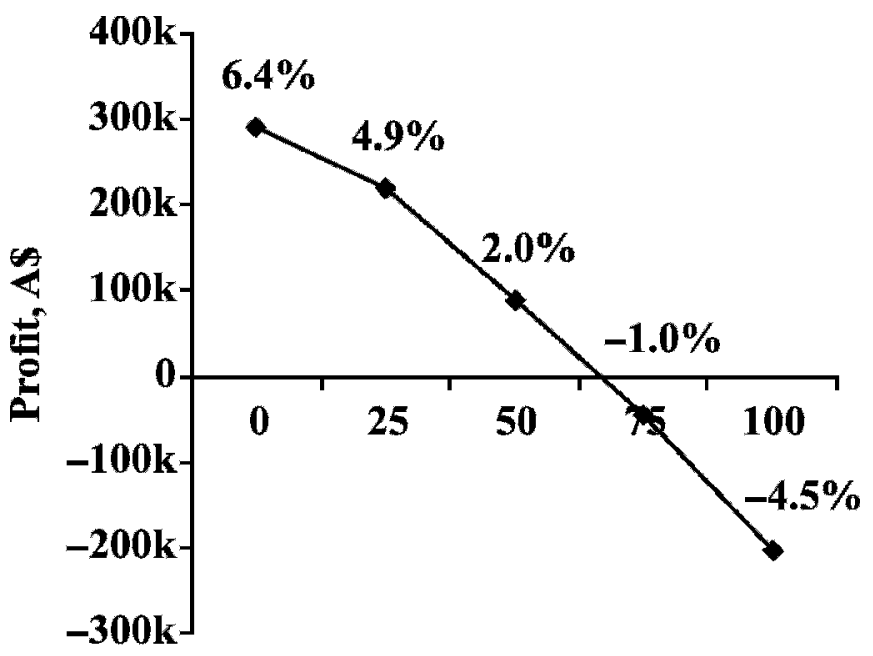

Area planted to corn/wheat, \%

Figure 8. Profit ( $\bullet, \mathrm{A} \$$, thousands) and return on assets (\%) with increases in area planted to the corn/wheat combination.

minor adjustments occurred in other categories such as water, labor, and fertilizer requirements.

Further sensitivity analysis was performed by removing prairie grass, resulting in the introduction of a large area of red clover and a lesser area of the kikuyu/rape combination as well as increases in the use of the corn/ rape combination. Introducing some corn reduced the need for energy supplements and the use of rape increased winter production. Removing prairie grass led to a much more significant reduction in return on assets, from 6.1 to $5.2 \%$. Milk production fell by a further $1 \%$, while the most obvious affect on costs was the increase to account for harvesting and feeding out the corn.

Table 4. Optimal forage choice with the progressive removal of the most profitable forage

\begin{tabular}{lrcc}
\hline & \multicolumn{3}{c}{ Model } \\
\cline { 2 - 4 } Forage & Base & No RP & $\begin{array}{c}\text { No RP } \\
\text { or PR }\end{array}$ \\
\hline Perennial ryegrass (RP) & 110 & & \\
Prairie grass (PR) & 53 & 111 & \\
White clover & 19 & 37 & 21 \\
Kikuyu/annual ryegrass & 12 & 30 & 12 \\
Phalaris & & 16 & 31 \\
Corn/rape & & 2 & 20 \\
Red clover & & & 64 \\
Kikuyu/rape & 6 & 4 & 33 \\
Other & 6.4 & 6.1 & 19 \\
Return on assets, \% & & & 5.2 \\
\hline
\end{tabular}

\section{Sensitivity}

Seasonal Milk Prices. Processors can use different milk prices through the year to encourage production when it is more costly to produce milk, or reduce prices when milk is relatively cheap to produce. In some areas of Australia, such as southern NSW and Victoria, a 2price system operates with a higher price from February to July and a lower price from August to January. The model was solved again with a seasonal 2-price system with a low price of $\mathrm{A} \$ 0.305 / \mathrm{L}$ and a high price of $\mathrm{A} \$ 0.355 / \mathrm{L}$, averaging the same $\mathrm{A} \$ 0.33 / \mathrm{L}$ as with the uniform milk price.

With the introduction of seasonal pricing, the major response in the model was to change 4 ha to perennial ryegrass from other species. Modest increases in milk production occurred during the months of the higher milk prices through higher levels of feeding per cow (Figure 9). Profit increased by only A $\$ 1,000$, and return on assets increased from 8.9 to $9.0 \%$.

Seasonal Calving Pattern. The base model was constrained by ensuring year-round calving, a common practice in NSW. This constraint was relaxed allowing cows to be calved in any month, although the maximum number of cows calved during the year was still limited to 800 . No area was planted to white clover and the kikuyu/annual ryegrass mix, freeing up 41 ha that was spread mainly between the other species from the base scenario, but with a small amount of the kikuyu/rape mix being sown. Milk production sharply peaked in October and slumped in March as a result of a higher proportion of cows calving between April and June (Figure 9). The increase in return on assets was modest, going from $6.4 \%$ in the base case to $6.5 \%$, implying that simply introducing seasonal calving was not highly profitable.

Seasonal Milk Prices and Seasonal Calving Pattern. The model was then used to estimate the farmer's best response under both seasonal prices and seasonal calving. The area planted to perennial ryegrass and prairie grass was similar to the base case, although the 12 ha of kikuyu/annual ryegrass were changed to kikuyu/rape and kikuyu/wheat. Milk production in October was more peaked than the base case, but less peaked than with uniform prices and seasonal calving. March milk production was lower than the base case, but higher than the uniform pricing/year-round scenario. The return on assets was $6.5 \%$, with profit only slightly lower than the uniform prices and seasonal calving scenario. These results show that farmers can respond to differential prices and alter their production pattern, although processors may need to make adjustments to the time and amount of price incentives to further flatten the milk production of their suppliers, 


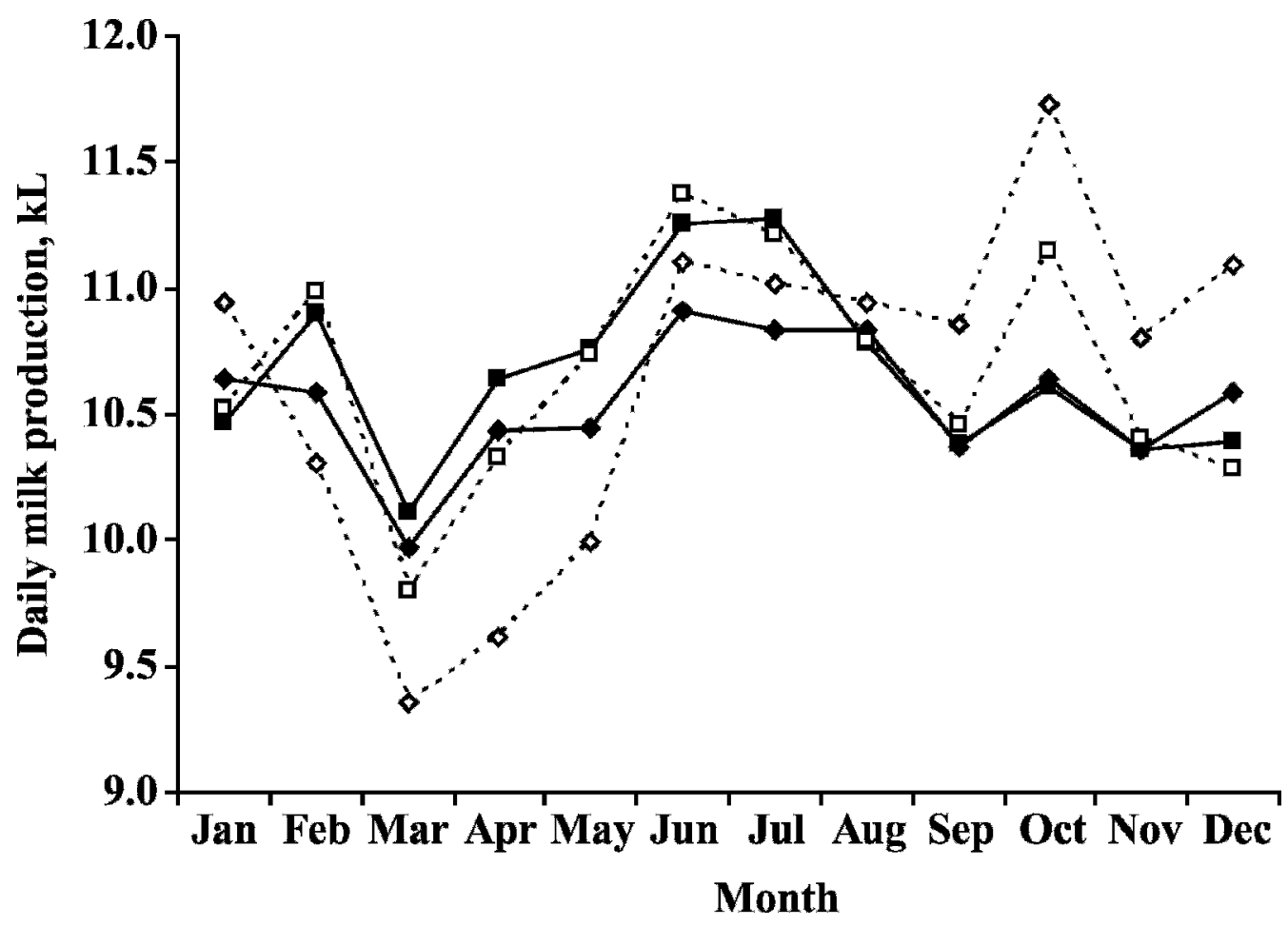

Figure 9. Effect on milk production of seasonal milk prices and seasonal calving: year-round calving with uniform price ( $\bullet$ ), year-round calving with seasonal prices $(\boldsymbol{\square})$, seasonal calving with uniform price $(\diamond)$, and seasonal calving with seasonal prices $(\square)$.

particularly if more suppliers intend to calve seasonally.

Water Price. To model the sensitivity of the farm's decisions to the annual water price, the water price was doubled from A $\$ 45 / \mathrm{ML}$ in the base model to A $\$ 90 / \mathrm{ML}$. If the farmer did not adjust behavior, return on assets fell by 0.8 to $5.6 \%$. This profit impact without adjustment was calculated as $\mathrm{A} \$ 45 / \mathrm{ML}$ multiplied by base water use of $810 \mathrm{ML}$. In the profit-maximizing solution there was only a modest change in the choice of species, with 16 ha moving to the kikuyu/rape and kikuyu/ wheat combination from the kikuyu/annual ryegrass combination. The effect on water use was a reduction of $2.5 \%$ from 810 to $790 \mathrm{ML}$. The return on assets was $5.6 \%$, the same as if no adjustment was made. This is because the value of adjusting forage areas and feeding strategies to the new price was relatively small, being less than $\mathrm{A} \$ 1,000$.

\section{CONCLUSIONS}

In this paper it was shown how a simple LP model can be used as a decision tool to select the most desirable mix of species on a farm based on the agronomic data obtained for the forage species evaluated at Camden. The LP allows selection to be based on various criteria, including profit maximization. It was found to be most profitable to use a mix of forage species rather than choosing a single forage or combination of forages based on alternative criteria that did not maximize profit. It was also found that the optimum mix of species was not much more profitable than using one of the most common forage species, perennial ryegrass, in the subtropical environment and under irrigation. Progressively removing prairie grass and perennial ryegrass from the available alternatives also did not cause large reductions in profit. We found that the ability to seasonally calve and adjust to seasonal milk prices did not make a large difference to overall profit or the mix of species, but it did affect the optimal calving pattern. The modest effect of increased water price on the model farm suggested that some farmers might not respond to increased prices with changes in forage areas. However, for farms that have less efficient technology (e.g., flood irrigation), a response such as investing in center pivot irrigation could occur, subsequently affecting forage choice. Further, for farms that have a lower profit margin than the base farm, significant increases in water prices may result in a response where they exit the industry.

There were several limitations in the current study. First, risk in terms of price or production risk was not considered. This could be addressed by using a statebased representation of uncertainty as suggested by 
Chambers and Quiggin (2000). Second, the model assumed that each forage required a certain level of water for a fixed production level, disallowing potential responses by altering irrigation levels. Data from the forage experiment could be used to estimate the response of forage growth to additional (or reduced) irrigation. Third, the model does not currently model the ability to substitute capital for labor or other inputs. These possibilities could be incorporated with integer variables to represent the availability of capital items. Fourth, technological changes, such as the availability of improvements in the genetic merit of cattle, were not included in the model. However, they could be incorporated through a multiyear LP or dynamic programming approach. Fifth, the digestibility-based intake model of the cow could be improved to increase the reliability of predictions. This may not be easily done in a LP model, but optima suggested by the LP model may be verified by using a more complex nutrition model (e.g., Kolver et al., 1998) or even tested in field experiments with animals. Finally, other limitations of the current work include the climatic region of applicability and the potential that farms with different objectives, constraints, or managerial ability will have different optimal forage mixes.

Despite these limitations, it could be concluded that a mix of forages similar to the model's optimum will be profitable in locations comparable to those where the forage experiment was carried out. Furthermore, in determining the optimal mix, emphasis should be placed on applying knowledge about the yield and nutritive characteristics of forages into a whole-farm context, taking into account the costs of growing and feeding them, as well as the ability to substitute with other inputs such as purchased feeds, fertilizer, water, labor, and capital.

\section{ACKNOWLEDGMENTS}

The authors thank reviewers of the Journal of Dairy Science for their help and critical comments that shaped the manuscript into its final version.

\section{REFERENCES}

ABARE. 2006. Australian dairy. DairyAustralia, Melbourne, Australia.

ARC (Agricultural Research Council). 1980. Nutrient Requirements of Ruminant Livestock. Commonwealth Agric. Bureaux, Farnham Royal, Slough, UK.

Batterham, R. L., T. MacAulay, R. Drynan, S. Whelan, S. Barnes, and J. Gooden. 1993. Are dairy farms big enough? Rep. to Australian Cooperative Foods, Univ. Sydney, Sydney, Australia.

Brooke, A., D. Kendrick, A. Meeraus, and R. Ramen. 2005. GAMS: A user's guide. GAMS Development Corp., Washington, DC.

Chambers, R. G., and J. Quiggin. 2000. Uncertainty, Production, Choice and Agency: The state-contingent approach. Cambridge Univ. Press, Cambridge, UK.
Earle, D. F. 1976. A guide to scoring dairy cow condition. J. Agric. (Victoria) 74:228-231.

Fulkerson, W. J. 2000. The productivity of Friesian cows: Effect of genetic merit and level of concentrate feeding. Final Rep. to the Dairy Research and Development Corporation. Dairy Res. Devel. Corp., Melbourne, Australia.

Fulkerson, W. J., and D. J. Donaghy. 2001. Plant-soluble carbohydrate reserves and senescence - key criteria for developing an effective grazing management system for ryegrass-based pastures: A review. Aust. J. Exp. Agric. 41:261-275.

Fulkerson, W. J., J. F. M. Fennell, and K. Slack. 2000. Production and forage quality of prairie grass (Bromus willdenowii) in comparison to perennial ryegrass (Lolium perenne) and tall fescue (Festuca arundinacea) in subtropical dairy pastures. Aust. J. Exp. Agric. 40:1059-1068.

Fulkerson, W. J., K. J. Lowe, J. F. Ayres, and T. Launders. 1993. Northern dairy feedbase: 3 Winter pasture and crops. Trop. Grassl. 27:162-179.

Fulkerson, W. J., J. S. Neal, C. J. Clark, A. Horadagoda, K. S. Nandra, and I. Barchia. 2007. Nutritive value of forage species grown in the warm temperate climate of Australia for dairy cows: Grasses and legumes. Livest. Sci. 107:253-364.

Holmes, C. W., I. M. Brookes, D. J. Garrick, D. D. S. MacKenzie, T. J. Parkinson, and G. F. Wilson. 2002. Milk production from pasture. Massey Univ. Press, Palmerston North, New Zealand.

Hulme, D. J., R. C. Kellaway, P. J. Booth, and L. Bennett. 1986. The CAMDAIRY model for formulating and analysing dairy cow rations. Agric. Syst. 22:81-108.

Kolver, E. S., L. D. Muller, M. C. Barry, and J. W. Penno. 1998. Evaluation and application of the Cornell Net Carbohydrate and Protein System for dairy cows fed diets based on pasture. J. Dairy Sci. 81:2029-2039.

McCall, D. G., and D. A. Clark. 1999. Optimized dairy grazing systems in the northeast United States and New Zealand. II. System analysis. J. Dairy Sci. 82:1795-1807.

McMeekan, C. P. 1956. Grazing management and animal production. VII International Grassland Congr., Palmerston North, New Zealand. 7:146-156.

Mertens, D. R. 1997. Creating a system for meeting the fiber requirements of dairy cows. J. Dairy Sci. 80:1463-1481.

Moran, J. B., and T. E. Trigg. 1985. Full feeding of dairy cows on maize silage based diets. Pages 181-183 in The Challenge: Efficient Dairy Production. T. I. Phillips, ed. Aust. Soc. Anim. Prod., Wodonga, Australia.

Neal, J., W. Fulkerson, R. Lawrie, K. S. Nandra, A. Horadagoda, P. Beale, H. Kingston, P. Looby, W. van Kouterik, and D. Lam. 2005. Development of a more suitable forage base for the dairy industry. Dairy Res. Found. Symp. 10:65-72.

Neal, M. 1999. Modelling seasonal production on a NSW dairy farm. Unpublished Thesis. Dept. Agric. Resource Econ., Univ. of Sydney, Australia.

NRC. 2001. Nutrient Requirements of Dairy Cattle. 7th rev. ed. Natl Acad. Sci., Washington, DC.

NSW DPI. 2006. Guide to tractor and machinery costs. NSW DPI. Orange. http://www.agric.nsw.gov.au/reader/machine+water Accessed Dec. 16, 2006.

Olney, G. R., and G. J. Kirk. 1989. A management model that helps increase profit on western Australian dairy farms. Agric. Syst. 31:367-380.

SCA. 1990. Feeding standards for Australian livestock: Ruminants. Standing Comm. Agric. Ruminants Subcommittee. CSIRO, East Melbourne, Australia.

Tozer, P. R., and R. G. Huffaker. 1999. Dairy deregulation and lowinput dairy production: A bioeconomic evaluation. J. Agric. Resource Econ. 24:155-172.

Vladiveloo, J., and W. Holmes. 1979. The prediction of the voluntary feed intake of dairy cows. J. Agric. Sci. 93:553-562.

Wood, P. D. P. 1980. Breed variations in the shape of the lactation curve of cattle and their implications for efficiency. Anim. Prod. 31:133-141. 